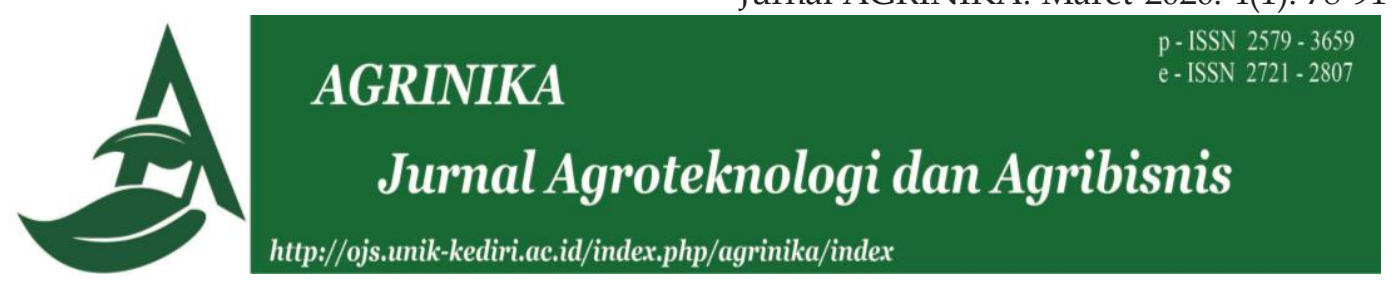

\title{
Analisis Usaha Ayam Ras Petelur di Desa Klurahan Kecamatan Ngronggot Kabupaten Nganjuk
}

\author{
Ade Galuh Rakhmadevi ${ }^{1 *}$, Danu Indra Wardhana ${ }^{2}$ \\ ${ }^{1}$ Program Studi Teknologi Industri Pangan, Politeknik Negeri Jember, Jember, Indonesia \\ ${ }^{2}$ Fakultas Pertanian, Universitas Muhammadiyah Jember, Jember, Indonesia \\ *Korespondensi: rakhmadevi@polije.ac.id \\ Diterima xx xx xxxx / Disetujui xx xx xxxx
}

\begin{abstract}
ABSTRAK
Dewasa ini, pola kehidupan masyarakat semakin meningkat, salah satunya dapat dilihat dari tingginya asupan gizi, terutama yang mengandung protein. Salah satu protein hewani yang paling umum dikonsumsi masyarakat adalah berasal dari telur. Umumnya telur yang dikonsumsi berasal dari jenis-jenis burung, seperti ayam, bebek, dan angsa, akan tetapi telur-telur yang lebih kecil seperti telur ikan kadang juga digunakan sebagai campuran dalam hidangan. Namun dari berbagai jenis telur tersebut telur ayam ras yang paling diminati oleh masyarakat dibanding telur lainnya. Adapun tujuan dari penelitian adalah untuk mengetahui besar biaya produksi yang digunakan dalam usaha ayam ras jenis ayam petelur, untuk mengetahui variabel tidak tetap yang mempengaruhi jumlah produksi telur dari ayam petelur, dan untuk mengetahui keuntungan peternakan ayam ras jenis ayam petelur. Hasil dari penelitian menunjukkan bahwa pendapatan yang diperoleh dalam usaha beternak Ayam Ras Jenis Ayam Petelur, dengan skala usaha 500 ekor adalah Rp155.694.300,00, untuk skala usaha 1.500 ekor adalah Rp523.455.51400, dan untuk skala usaha lebih dari 5000 ekor adalah Rp1.850.211.903,00. Faktor yang berpengaruh sangat signifikan terhadap besarnya produksi ternak ayam ras jenis ayam petelur adalah faktor pakan (X2) sebesar 9,7073 dan usaha ternak ayam ras petelur termasuk menguntungkan.
\end{abstract}

Kata kunci : Analisis; Ayam ras petelur; Pakan; Pendapatan; Telur

\begin{abstract}
Nowadays, the pattern of people's life style is increasing, one of which can be seen from the high intake of nutrients, especially those containing protein. One of the most commonly consumed animal proteins comes from eggs. Generally, eggs consumed come from bird species, such as chickens, ducks, and geese, but smaller eggs such as fish eggs are sometimes also used as a mixture in dishes. However, of the various types of eggs, purebred chicken eggs are the most popular among the public compared to other eggs. The purpose of this study was to determine the amount of production costs used in the business of purebred laying hens, to determine the variable which affects the amount of egg production from laying hens, and to determine the advantages of breeding broilers of laying hens. The results of the study showed that the income obtained in the business of raising laying chickens, with a business scale of 500 chickens was IDR $155,694,300.00$, for a business scale of 1,500 was IDR $523,455,51400$, and for a business scale of more than 5,000 was IDR1,850,211,903.00. Factors that had a significant effect on the amount of production of purebred laying hens was the feed factor (X2) of 9.7073 and the business of laying hen was profitable.
\end{abstract}

Key words : Analysis; Eggs; Feed; Income; Purebred laying hens 


\section{PENDAHULUAN}

Meningkatnya jumlah penduduk semakin diimbangi dengan arti penting kesehatan dalam kehidupan. Hal ini berimplikasi pada pola konsumsi makanan yang juga akan terus meningkat. Meningkatnya pola kehidupan masyarakat mengakibatkan tingginya asupan gizi terutama yang mengandung protein, salah satu protein hewani dapat berasal dari telur.

Telur adalah salah satu bahan makanan hewani yang dikonsumsi selain daging, ikan dan susu. Umumnya telur yang dikonsumsi berasal dari jenisjenis burung, seperti ayam, bebek, dan angsa, akan tetapi telur-telur yang lebih kecil seperti telur ikan kadang juga digunakan sebagai campuran dalam hidangan. Namun dari berbagai jenis telur tersebut telur ayam ras yang paling diminati oleh masyarakat dibanding telur lainnya. Hal ini dikarenakan jumlah telur itik dan ayam kampung sedikit dipasaran dan harganya mahal, sedangkan permintaan masyarakat yang tinggi maka masyarakat lebih memilih telur ayam yang lebih murah dengan jumlah yang banyak. Permintaan yang besar merupakan peluang usaha yang tinggi bagi peternak ayam petelur mengembangkan usaha (Arif, 2017).

Peternakan adalah kegiatan mengembangbiakan dan membudidayakan hewan ternak untuk mendapatkan manfaat dan hasilnya. Tujuan peternakan adalah mencari keuntungan dengan penerapan prinsip manajemen pada faktor-faktor produksi yang telah dikombinasi secara optimal. Salah satu paramenter yang dapat dipergunakan untuk mengukur keberhasilan suatu usaha adalah secara efisien.
Beberapa hal yang menyebabkan kemajuan tersebut adalah adannya perbaikan tehnologi pengolahan ayam petelur yang berupa: perkandangan, bibit unggul, pakan yang berkualitas, sanitasi dan vaksin. Tujuan perkembangan usaha peternakan ayam petelur adalah untuk memenuhi kebutuhan pangan dan gizi masyarakat pada sektor rumah tangga oleh pihak konsumen. Tujuan yang ingin dicapai oleh pihak produsen dalam mengusahakan peternakan ayam petelur adalah untuk mendapatkan keuntungan guna untuk mencukupi kebutuhan hidup dan meningkatnya usahanya (Maulana, et. al., 2017).

Produksi adalah suatu kegiatan mengolah suatu barang menjadi barang setengah jadi maupun menjadi barang jadi. Para peternak ayam petelur sering dihadapkan pada keadaan dimana ayam petelur tidak dapat menghasilkan hasil produksi yang optimal. Rendahnya pendapatan karena tidak adanya saluran pemasaran yang jelas dalam menentukan harga dari harga input maupun harga output. Penggunaan faktor-faktor produksi diusahakan agar dalam jumlah tertentu menghasilkan produksi maksimal dan keuntungan tertinggi (Azzury, 2013)

Sejauh ini di Desa Klurahan Kecamatan Ngronggot Kabupaten Nganjuk belum ada penelitian yang mengamati tentang ayam ras jenis ayam petelur, maka dari itu dilakukan penelitian tersebut.

Penelitian ini dilakukan untuk menghitung besarnya biaya produksi yang digunakan dalam usaha ayam ras jenis ayam petelur, mengetahui variabel tidak tetap apakah yang berpengaruh terhadap produksi telur dari ayam ras jenis ayam petelur, dan menganalisis 
apakah usaha peternakan ayam ras jenis ayam petelur menguntungkan.

Adapun tujuan dari penelitian adalah untuk mengetahui besar biaya produksi yang digunakan dalam usaha ayam ras jenis ayam petelur, untuk mengetahui variabel tidak tetap yang mempengaruhi jumlah produksi telur dari ayam petelur, dan untuk mengetahui keuntungan peternakan ayam ras jenis ayam petelur.

Penelitian diharapkan dapat bermanfaat bagi peternak untuk mengetahui tingkat biaya dalam beternak ayam petelur dan mengetahui keuntungan yang diperoleh dari beternak ayam ras jenis ayam petelur. Di samping itu, bagi pengembangan ilmu, diharapkan hasil penelitian ini dapat dijadikan referensi bagi peneliti selanjutnya, sehingga dapat memperbaiki keterbatasan dalam penelitian ini.

\section{BAHAN DAN METODE}

Jenis penelitian yang digunakan adalah studi kasus. Penelitian yang mendalam terhadap suatu keadaan atau kejadian yang disebut sebagai kasus dengan menggunakan cara-cara yang sistematis dalam melakukan pengamatan, pengumpulan data, analisis informasi, dan pelaporan hasilnya (Romadhon, et. al., 2012). Studi kasus pada penelitian ini menggunakan obyek penelitian yang terdapat di Desa Klurahan Kecamatan Ngronggot Kabupaten Nganjuk.

\section{Metode Penentuan Lokasi}

Lokasi penelitian dipilih dengan pertimbangan-pertimbangan tertentu, peternakan di Desa Klurahan Kecamatan Ngronggot tersebut memiliki beberapa peternak yang kurang lebih mencapai 20 peternak yang pemeliharaan ayam petelur tersebut kurang lebih sebanyak $5.000-10.000$ ekor ayam petelur, rata-rata para peternak di Desa Klurahan sudah berjalan sekitar 5 tahun. Berdasarkan pertimbangan tersebut maka para peternak ayam petelur di Desa Klurahan Kecamatan Ngronggot Kabupaten Nganjuk terpilih sebagai obyek penelitian.

\section{Metode Penentuan Sampel}

Penelitian ini menggunakan metode sensus terhadap populasi petelur yang ada yaitu sebesar 20 peternak ayam ras jenis ayam petelur di Desa Klurahan Kecamatan Ngronggot Kabupaten Nganjuk.

\section{Metode Pengumpulan Data}

Data yang diperlukan meliputi data primer dan data sekunder. Metode pengumpulan data dilakukan melalui wawancara dengan alat bantu daftar pertanyaan (kuesioner). Sedangkan observasi yaitu proses pencatatan pola perilaku subyek (orang), obyek (benda) atau kejadian yang sistematik tanpa adanya pertanyaan atau komunikasi dengan individu yang diteliti.

Data sekunder diperoleh dari berbagai instansi atau lembaga yang terkait dalam penelitian ini. Data sekunder yang diambil meliputi topografi, monografi dan klimatologi wilayah setempat. (Marzuki, 2013).

\section{Metode Analisis Data}

Data yang telah terkumpul ditabulasi untuk mempermudah dalam analisis, sedangkan untuk mengetahui pengaruh faktor produksi digunakan analisis Regresi linier dengan rumus sebagai berikut:

$Y: b 1 \times 1+b 2 \times 2+b 3 \times 3+b 4 \times 4$

Dimana :

Y : Produksi $(\mathrm{kg})$ 


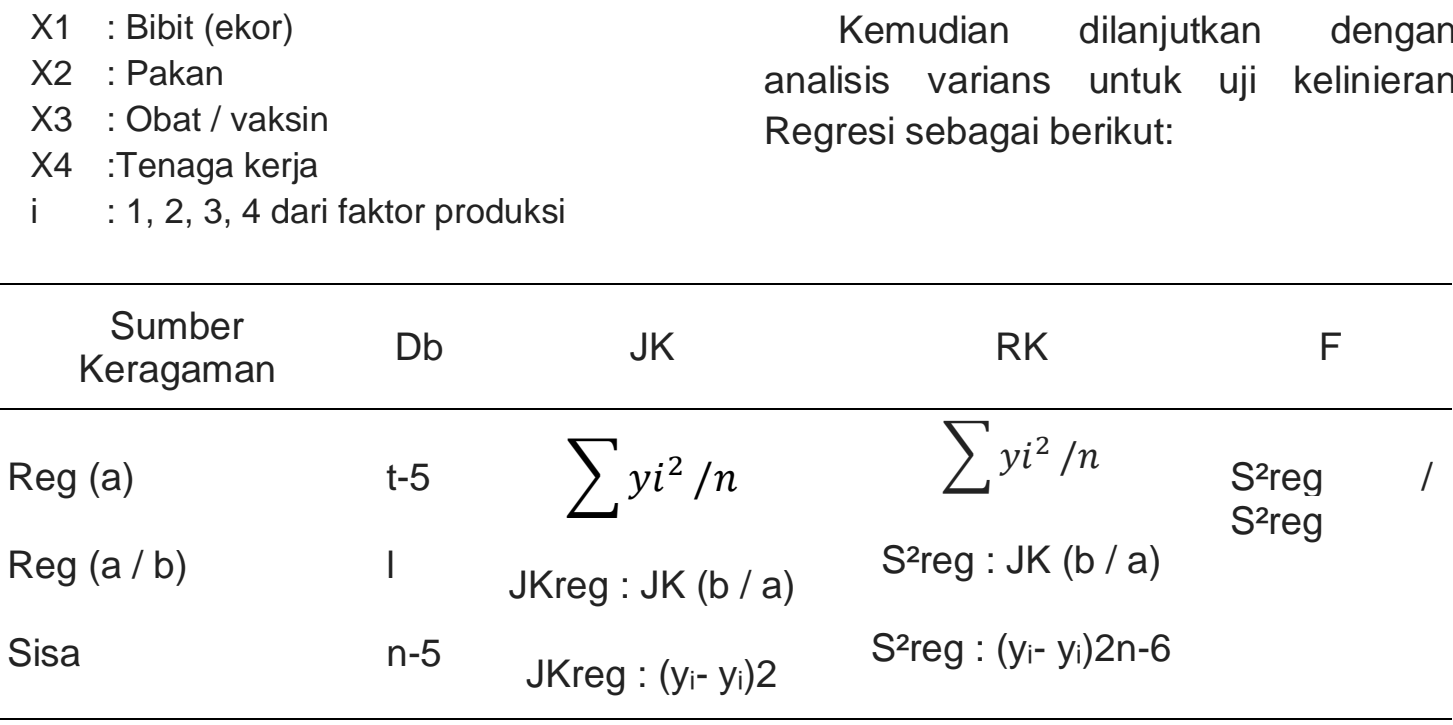

Untuk mengetahui semua faktor yang berpengaruh terhadap pendapatan usaha pembesaran ayam petelur dapat digunakan uji $\mathrm{F}$ dengan rumus sebagai berikut:

Fhitung : $\frac{\text { RK Regresi }}{\text { RK Sisa }}$

Kriteria pengambilan keputusan:

a. Jika $F$ hitung $>F$ tabel $(0,05)$ ada kelinieran regresi.

b. Jika $F$ hitung $\leq F$ tabel $(0,05)$ maka $H_{0}$ tidak ada kelinieran regresi.

Untuk mengetahui pengaruh tiap variabel terhadap produk digunakan uji $t$ sesuai dengan metode pada penelitian Ulfa, et. al. (2014) dengan rumus sebagai berikut :

Thitung $: \frac{b_{1}}{S c b_{1}}$......

Kriteria pengambilan keputusan :

a. Jika $t$ hitung $>t$ tabel $(0,05)$ maka $H_{\circ}$ ditolak, dan $\mathrm{H}_{\mathrm{i}}$ diterima, yang berarti bahwa variabel independen berpengaruhnya terhadap produksi.

b. Jika $\mathrm{t}$ hitung $\leq \mathrm{t}$ tabel $(0,05)$ maka $\mathrm{H}_{\mathrm{o}}$ diterima, dan $\mathrm{H}_{\mathrm{i}}$ ditolak, yang berarti bahwa variabel independen tidak berpengaruh nyata terhadap produksinya.

Untuk mengetahui berapa besarnya pendapatan bersih usaha pembesaran ayam petelur, digunakan rumus sebagai berikut :

TC : FC + VC.

Dimana :

TC : Total Cost (keseluruhan biaya yang dikeluarkan pengusaha pembesaran ayam petelur)

FC : Fixed Cost (biaya tetap)

VC : Variabel Cost (besarnya biaya yang dikeluarkan yang dipengaruhi oleh besarnya pendapatan) (Prayogo, et. al., 2018).

Kriteria pengambilan keputusan :

1 Jika $\Omega>0$, berarti bahwa usaha tersebut mengalami keuntungan.

2 Jika $Л=0$, berarti usaha tersebut impas.

3 Jika $\Omega<0$, berarti bahwa usaha tersebut rugi.

Untuk mengetahui besarnya pendapatan usaha pembesaran ayam petelur :

ת : $\mathrm{TR}-\mathrm{TC}$

Dimana :

$$
\begin{array}{ll}
\text { Л } & : \text { Pendapatan } \\
\text { TR } & : \text { Total penerimaan } \\
\text { TC } & : \text { Total biaya }
\end{array}
$$

Untuk mengetahui efisinsi digunakan rumus : 
$R / C$ Ratio $=\frac{\text { pendapatan }}{\text { biaya }}$

Kriteria pengambilan keputusan :

1. R / C Ratio > 1, berarti usaha tersebut menguntungkan.

2. $\mathrm{R} / \mathrm{C}$ Ratio < 1, berarti usaha tersebut tidak menguntungkan.

Penelitian dilaksanakan di Desa Klurahan Kecamatan Ngronggot Kabupaten Nganjuk. Pelaksanaan penelitian dimulai pada bulan Februari sampai dengan Maret 2019. Lokasi penelitian ditentukan secara sengaja di Desa Klurahan Kecamatan Ngronggot Kabupaten Nganjuk dengan berdasarkan tujuan penelitian. Pemilihan lokasi berdasarkan peternakan tersebut telah beroperasi lebih dari satu tahun.

\section{HASIL DAN PEMBAHASAN}

\section{Karateristik Responden}

Karakteristik peternak responden menggambarkan tentang keadaan dari peternak itu sendiri baik dari segi umur dan pendidikan. Karakteristik peternak responden di Desa Klurahan yang dijadikan sampel penelitian sebanyak 20 responden yang memiliki ayam petelur. Karateristik petani responden secara rinci dapat dilihat pada Tabel 1.

Berdasarkan Tabel 1 diperoleh informasi bahwa usia peternak responden yang berusia 45 tahun ke atas yakni 13 orang $(43,00 \%)$, dan yang terendah adalah usia 25 tahun sampai 34 tahun yakni 8 orang $(26,67 \%)$. Usaha ayam ras petelur kebanyakan dilakukan oleh penduduk yang sudah cukup usia, yaitu di atas 45 tahun.

Di dalam melakukan kegiatan usaha tani setiap petani mempunyai tuntutan yang bersifat ekonomis, dimana dalam usaha tersebut bertujuan untuk memperoleh suatu keuntungan produksi yang tinggi atau maksimal (Cahyono,
2015). Akan tetapi belum dapat dikatakan bahwa usaha tani tersebut efisien kalau dalam penggunaan faktorfaktor produksi belum bisa seefektif mungkin, hal ini ada kaitannya dengan kemampuan cara mengkombinasi serta mengalokasi penggunaan faktor-faktor yang tersedia seefektif mungkin. Biaya merupakan salah satu faktor penting dalam bidang pertanian sehingga dengan biaya yang cukup akan bisa mempelancar proses usaha petani yang berkaitan dengan faktor-faktor produksi yang sudah ada yang akhirnya dapat memperoleh pendapatan yang diharapkan, sehingga tercapailah kesejahteraan hidup petani khususnya di pedesaan (Subagja, et. al., 2017).

Faktor pendidikan diharapkan dapat membantu masyarakat dalam upaya peningkatan produksi dan produktifitas ternak yang dipelihara. Tingkat pendidikan yang memadai akan berdampak pada peningkatan kinerja dan kemampuan dalam peternakan yang dijalani (Kurniawan, et. al., 2018). Berdasarkan Tabel 1 di atas dapat dilihat bahwa peternak yang pendidikannya sampai bangku SMP sebanyak 2 orang, sedangkan yang pendidikannya sampai bangku SMA sebanyak 15 orang dan yang pendidikannya sampai bangku perkuliahan S-1 sebanyak 3 orang. Dari data di atas dapat disimpulkan bahwa peternak yang terdapat di Desa Klurahan Kecamatan Ngronggot Kabupaten Nganjuk paling banyak lulusan bangku Sekolah Menengah Atas (SMA) yaitu sebanyak 15 orang.

Faktor pengetahuan yang dimiliki oleh peternak bertujuan untuk membantu dalam proses produksi ayam petelur agar dapat menghasilkan hasil produksi yang maksimal. Pengetahuan yang diperoleh para peternak di Desa 
Klurahan Kecamatan Ngronggot Kabupaten Nganjuk yaitu melalui metode penyuluhan langsung yang biasanya terdapat di Balai Desa Klurahan, dalam kursus tani dan obrolan di tempat peternakan antar peternak. Namun ada juga yang melakukan metode penyuluhan tidak langsung yaitu melalui bantuan perantara (media). Misalnya penyuluh yang menyampaikan penyuluhannya melalui radio, internet atau televisi.

Pengalaman beternak merupakan lamanya peternak (responden) menggeluti usaha peternakan Ayam Petelur (Sartika \& Rahmi, 2012). Sebagian peternak Ayam Petelur di Desa Klurahan Kecamatan Ngronggot Kabupaten Nganjuk merupakan usaha peternakan yang turun menurun. Dengan adanya pengalaman beternak merupakan modal yang penting untuk dapat menghasilakn suatu kegiatan beternak yang maksimal.
Berdasarkan Tabel 1 dapat dilihat bahwa peternak (responden) yang telah memiliki pengalaman beternak ayam petelur selama $1-7$ tahun sebanyak 5 orang, yang memiliki pengalaman beternak ayam petelur selama $8-15$ tahun sebanyak 8 orang dan yang memiliki pengalaman beternak ayam petelur lebih dari 16 tahun yaitu sebanyak 7 orang.

Modal adalah investasi awal yang dilakukan peternak dalam usaha beternak Ayam Petelur (Sari, 2014). Biasanya modal dalam usaha beternak ayam petelur berasal dari pinjam bank atau milik pribadi. Namun modal yang terdapat di Desa Klurahan Kecamatan Ngronggot Kabupaten Nganjuk berasal dari milik pribadi. Karena jika modal berasal dari pinjaman bank maka hal itu akan memberatkan peternak dengan beban bunga bank yang cukup tinggi.

Tabel 1. Karakteristik petani responden

\begin{tabular}{|c|c|c|c|}
\hline No & Karakteristik Responden & Frekuensi & Presentase (\%) \\
\hline \multirow[t]{4}{*}{1.} & Usia (tahun): & & \\
\hline & $25-34$ tahun & 8 & 26,67 \\
\hline & $35-44$ tahun & 9 & 30,00 \\
\hline & 45 tahun ke atas & 13 & 43,00 \\
\hline \multirow[t]{5}{*}{2.} & Pendidikan: & & \\
\hline & SD & 0 & 0 \\
\hline & SMP & 2 & 10 \\
\hline & SMA & 15 & 75 \\
\hline & S-1 & 3 & 15 \\
\hline \multirow[t]{4}{*}{3.} & Pengalaman beternak (tahun): & & \\
\hline & $1-7$ & 5 & 25 \\
\hline & $8-15$ & 8 & 40 \\
\hline & $>16$ & 7 & 35 \\
\hline \multirow[t]{3}{*}{4.} & Modal: & & \\
\hline & Pribadi & 20 & 100 \\
\hline & Pinjaman & 0 & 0 \\
\hline & Total & 20 & 100 \\
\hline
\end{tabular}

Sumber: Data primer diolah 2019 


\section{Analisis Usaha Tani}

\section{Biaya Usaha}

Usaha peternakan ayam petelur di Desa Klurahan Kecamatan Ngronggot Kabupaten Nganjuk diperlukan dua macam biaya yaitu biaya tetap dan biaya tidak tetap. Biaya tetap terdiri dari biaya penyusutan kandang, penyusutan gudang, penyusutan peralatan, penyusutan instalasi air, penyusutan instalasi listrik, listrik dan upah tenaga kerja. Biaya tidak tetap terdiri dari biaya bibit ayam petelur (DOC), pakan, vaksin / obat - obatan, dan perbaikan kandang.

$$
\text { Biaya tetap merupakan }
$$
penggunaan modal untuk menghasilkan lebih banyak uang melalui sarana yang lebih menghasilkan pendapatan (Rahmi, et. al., 2006). Investasi usaha peternak ayam petelur terdiri dari bangunan kandang, gudang dan peralatan kandang yang tidak habis digunakan dalam jangkan waktu satu tahun.

Biaya tetap yang digunakan untuk pembangunan kandang tertinggi pada skala usaha $>5.000$ ekor dan terendah pada skala usaha $500-1.500$ ekor. Investasi yang digunakan untuk pembangunan gudang tertinggi pada skala usaha $>5.000$ ekor dan terendah pada skala usaha $500-1.500$ ekor. Investasi yang digunakan untuk pembelian peralatan kandang tertinggi pada skala usaha $>5.000$ ekor dan terendah pada skala usaha $500-1.500$ ekor.

Tabel 2. Biaya tetap usaha tani jamur tiram berdasarkan skala usaha

\begin{tabular}{ccccc}
\hline \multirow{2}{*}{ No } & \multirow{2}{*}{ Biaya Tetap } & \multicolumn{3}{c}{ Skala usaha } \\
\cline { 3 - 5 } & Kandang & $\mathbf{5 0 0}$ & $\mathbf{1 5 0 0}$ & $\mathbf{5 . 0 0 0}$ \\
\hline 1 & $85.000 .000,00$ & $255.000 .000,00$ & $850.000 .000,00$ \\
2 & Peralatan & $48.290 .390,00$ & $144.871 .170,00$ & $482.903 .900,00$ \\
\hline \multicolumn{2}{c}{ Total } & $133.290 .390,00$ & $399.871 .170,00$ & $1.332 .903 .900,00$ \\
\hline
\end{tabular}

Sumber: Data primer diolah 2019

Biaya variabel yang akan dibahas pertama kali adalah biaya bibit. Biaya bibit yang paling besar dikeluarkan untuk bibit oleh peternak yaitu pada skala $>5000$ ekor yaitu sebesar Rp. 20.000.000 selama satu periode $(1,5$ tahun). Sedangkan biaya bibit yang paling sedikit pada skala usaha 500 ekor yaitu sebesar Rp 2.000.000 selama satu periode (1,5 tahun).

Biaya pakan yang paling besar dikeluarkan pada skala $>5000$ ekor sebesar Rp 259.200.000 selama satu periode (1,5 tahun). Dan biaya pakan yang paling sedikit pada skala usaha 500 ekor sebesar Rp 86.400.000 selama satu periode (1,5 tahun). Selain itu terdapat beberapa peternak yang menambahkan campuran pakannya dengan suplemen seperti kunyit, Top Mix, dan Masamix.

Biaya kesehatan (vaksin / obatobatan) paling besar pada skala usaha $>5000$ ekor sebesar Rp 337.500.000 selama sati perode (1,5 tahun) dan biaya kesehatan (vaksin / obat-obatan) yang paling sedikit pada skala usaha 500 ekor sebesar Rp 33.750.000selama satu periode (1,5 tahun).

Biaya tenaga kerja paling besar dikeluarkan pada skala usaha $>5000$ ekor sebesar Rp 108.000.000 selama satu periode (1,5 tahun) dan biaya tenaga kerja yang paling sedikit pada skala usaha 500 ekor sebesar Rp 54.000.000 selama satu periode (1,5 
Ade Galuh Rakhmadevi \& Danu Indra Wardhana, Analisis Usaha Ayam ...

tahun). Sebagian besar peternak yang ada di Desa Klurahan menggunakan kerja yang mereka keluarkan lebih tenaga kerja luar, sehingga biaya tenaga

tinggi.

Tabel 3. Biaya tidak tetap usaha tani jamur tiram berdasarkan skala usaha

\begin{tabular}{llrrr}
\hline \multirow{2}{*}{ No } & \multirow{2}{*}{ Biaya Tidak Tetap } & \multicolumn{3}{c}{ Skala usaha (ekor) } \\
\cline { 2 - 5 } & Bibit & $\mathbf{5 0 0}$ & $\mathbf{1 5 0 0}$ & \multicolumn{1}{c}{$>\mathbf{5 0 0 0}$} \\
\hline 1 & 2.000 .000 & 6.000 .000 & 20.000 .000 \\
2 & Pakan & 86.400 .000 & 259.200 .000 & 864.000 .000 \\
3 & Vaksin & 33.750 .000 & 101.250 .000 & 337.500 .000 \\
4 & Tenaga Kerja & 54.000 .000 & 81.000 .000 & 108.000 .000 \\
\hline \multicolumn{2}{c}{ Total } & 176.150 .000 & 447.450 .000 & 1.329 .500 .000 \\
\hline
\end{tabular}

Sumber: Data primer diolah 2019

\section{Penerimaan dan Pendapatan}

Penerimaan dari usaha ayam ras petelur diperoleh dari produksi telur utuh, telur pecah, penjualan ayam afkir, feses dan karung (tempat pakan). Harga telur ayam yang dijual oleh peternak rata - rata Rp. 18.000,00 /kg, untuk penjualan kotoran ayam rata - rata $\mathrm{Rp}$. $10.000,00$ / kantong dan sedangkan untuk penjualan ayam afkir rata - rata Rp. 35.000,00 / ekor.

Berdasarkan tabel 5.3.1 penerimaan dari hasil penjualan telur ayam paling besar pada skala usaha $>5000$ ekor sebesar Rp 2.916.000.000,00 selama satu periode (1,5 tahun) dan penerimaan dari hasil penjualan telur ayam paling sedikit pada skala usaha 500 ekor sebesar Rp291.600.000,00 selama satu periode (1,5 tahun).

Ayam afkir merupakan ayam yang sudah tidak produksi secara maksimal dengan umur ayam berkisar 1,5 tahun (Nawawi, Arif Muhamad, 2017), sehingga dapat dijual dan bisa menjadi penerimaan tambahan. Berdasarkan tabel 5.3.1 penerimaan dari hasil penjualan ayam afkirpaling besar pada skala usaha $>5000$ ekor sebesar $\mathrm{Rp}$ 175.000.000,00 selama satu periode (1,5 tahun) dan penerimaan ayam afkir paling sedikit pada skala usaha 500 ekor sebesar Rp 17.500.000,00 selama satu periode ( 1,5 tahun).

Tabel 4. Penerimaan rata - rata peternak ayam ras petelur di Desa Klurahan Kecamatan Ngronggot Kabupaten Nganjuk

\begin{tabular}{rlrrr}
\hline \multirow{2}{*}{ No } & Jenis & \multicolumn{3}{c}{ Skala Usaha (ekor) } \\
\cline { 3 - 5 } & Penerimaan & \multicolumn{1}{c}{ 500 ekor } & 1500 ekor & \multicolumn{1}{c}{$\mathbf{> 5 0 0 0 \text { ekor }}$} \\
\hline 1 & Telur ayam & $R p 291.600 .000$ & $R p 874.800 .000$ & $R p 2.916 .000 .000$ \\
2 & Ayam afkir & $R p 17.500 .000$ & $R p 52.500 .000$ & $R p 175.000 .000$ \\
3 & Kotoran & $R p 40.500 .000$ & $R p 48.600 .000$ & $R p 86.400 .000$ \\
\hline & Jumlah & $R p 349.600 .000$ & $R p 975.900 .000$ & Rp3.177.400.000 \\
\hline
\end{tabular}

Sumber : Data primer terolah, 2019.

Berdasarkan Tabel 4 dapat dijelaskan bahwa penerimaan dari hasil penjualan kotoran paling besar pada skala usaha $>5000$ ekor sebesar $R p$ 86.400 .000 selama satu periode $(1,5$ tahun) dan penerimaan dari hasil 
penjualan kotoran paling sedikit pada skala usaha 500 ekor sebesar $\mathrm{Rp}$ 40.500.000 selama satu periode (1,5 tahun). Semakin besar skala usaha yang dikelola peternak maka akan semakin besar pula peningkatan pendapatan yang diperoleh dari hasil penjualan feses (Ngantung, et. al., 2019).

Sementara total biaya dan total penerimaan perlu diketahui untuk menghitung pendapatan suatu usaha (Mulyani \& Satriani, 2013)

Berdasarkan Tabel 5 dapat dijelaskan bahwa pendapatan dari usaha peternakan ayam petelur paling besar pada skaka $>5000$ ekor sebesar
Rp 1.850.211.903 dan pendapatan paling sedikit pada skala usaha 500 ekor sebesar Rp 155.694.300. Hasil analisis pada Tabel 5 tentang pendapatan peternak dapat memberikan suatu gambaran yang jelas tentang pentingnya seorang peternak mengembangkan usahanya walaupun dalam usaha tersebut memelurkan biaya produksi yang semakin besar. Biaya produksi yang besar dan seimbang dengan skala usaha maka tingkat pendapatan peternak akan semakin besar pula bila sistem pengelolahannya dilakukan secara optimal (Aida \& Alam, 2015).

Tabel 5. Penerimaan dan pendapatan usaha tani ayam ras petelur berdasarkan skala usaha

\begin{tabular}{ccrrr}
\hline No & Skala usaha & $\begin{array}{c}\text { Total Biaya } \\
(\mathbf{R p})\end{array}$ & Penerimaan (Rp) & \multicolumn{1}{c}{$\begin{array}{c}\text { Pendapatan } \\
(\mathbf{R p})\end{array}$} \\
\hline 1 & 500 ekor & 341.708 .333 & 186.014 .033 & 155.694 .300 \\
2 & 1500 ekor & 979.800 .000 & 456.344 .486 & 523.455 .514 \\
3 & $>5000$ & 3.190 .400 .000 & 1.340 .188 .097 & 1.850 .211 .903 \\
\hline
\end{tabular}

Sumber: Data primer diolah 2019

Faktor - faktor yang Berpengaruh Terhadap Produksi

Pengunaan faktor - faktor produksi terhadap peningkatan produksi usaha peternakan ayam ras petelur ini digunakan analisa produksi, sedangkan untuk parameter dari fungsi produksi tersebut digunakan fungsi produksi dalam model Regresi, maka untuk lebih jelasnya sebagian berikut :

$Y=0,022 X 1+9,707 \times 2+5,041 \times 3+0,305$ $\mathrm{X} 4$

$$
\begin{aligned}
& \text { Dimana: } \\
& \mathrm{X} 1=\text { Bibit } \\
& \mathrm{X} 2=\text { Pakan } \\
& \mathrm{X} 3=\text { Obat / vaksin } \\
& \mathrm{X} 4=\text { Tenaga kerja }
\end{aligned}
$$

Untuk mengetahui faktor - faktor yang berpengaruhi pada pendapatan usaha peternakan ayam ras petelur di
Desa Klurahan Kecamatan Ngronggot Kabupaten Ngronggot dalam satu periode (1,5 tahun).

a. Uji $F$

Berdasarkan hasil uji $F$ yaitu $F$ hitung lebih besar dari pada $F$ tabel pada taraf kepercayaan 95\% dari hasil yang didapatkan keterangan bahwa produksi yang benar-benar dipengaruhi oleh komoditas faktor-faktor produksi (Pamungkas \& Rahayu, 2020).

Uji $F$ merupakan alat yang digunakan untuk menguji apakah variabel independen berpengaruh secara bersamaan terhadap variabel dependen (Muhammad, et. al., 2017) Diperoleh nilah $F$ hitung sebesar 1248,69. Bila dibandingkan dengan $F$ tabel yaitu sebesar 1,00072 maka nilai $F$ hitung lebih besar dari $F$ tabel $(1248,69$ 
$>$ 1,00072). Berdasarkan perhitungan maka variabel berpengaruh terhadap pendapatan.

b. Uji $t$

Pengujian ini berupaya mengetahui apakah variabel independen berpengaruh secara signifikan terhadap variabel dependen secara individual (Santoso, et. al., 2017) Berdasarkan hasil regresi setelah perhitungan dapat disimpulan bahwa hanya variabel biaya tenaga kerja $\left(\mathrm{X}_{6}\right)$ yang berpengaruh secara signifikan terhadap pendapatan (Y) sedangkan variabel lainnya (biaya pakan, biaya bibit, biaya vaksin) secara individual tidak nyata berpengaruh terhadap variabel dependen karena nilai t-hitung masing - masing variabel lebih kecil dari pada nilai t-tabel. Ini juga dapat dibuktikan dengan nilai signifikan masing-masing variabel yang akan dijelaskan di bawah ini.

Tabel 6. Hasil uji t untuk mengetahui pengaruh tiap variabel terhadap produksi telur ayam petelur di Desa Klurahan Kecamatan Ngronggot Kabupaten Nganjuk, 2019.

\begin{tabular}{|c|c|c|c|c|c|}
\hline No & Variabel & koefisien & Nilai t - hitung & Nilai t - tabel & Keterangan \\
\hline 1 & $\mathrm{X} 1$ & 0,0229 & 0,0128 & 1,705 & $\begin{array}{c}\text { Tidak } \\
\text { signifikan }\end{array}$ \\
\hline 2 & $\mathrm{X} 2$ & 9,7073 & 1,8599 & 1,705 & $\begin{array}{c}\text { Sangat } \\
\text { signifikan }\end{array}$ \\
\hline 3 & X3 & 5,0417 & 1,2272 & 1,705 & $\begin{array}{c}\text { Tidak } \\
\text { signifikan }\end{array}$ \\
\hline 4 & $X 4$ & 0,3055 & 0,1498 & 1,705 & $\begin{array}{c}\text { Tidak } \\
\text { signifikan }\end{array}$ \\
\hline
\end{tabular}

\section{Variabel biaya bibit (X1)}

Bibit (DOC) merupakan salah satu faktor yang harus diperhatikan dalam usaha peternakan ayam petelur. Sebelum membeli bibit harus diketahui mengenai kelebihan atau kekurangan dari bibit tersebut. Karena bibit (DOC) yang akan digunakan merupakan gambaran dari titik awal kegiatan peternakan. Jika pembelian bibit (DOC) dari awal sudah jelek maka sulit bagi peternak untuk dapat mendapatkan hasil yang baik pula. Adanya hubungan positif dan negatif antara bibit dan pendapatan peternak (Primaditya, et. al., 2015).

Hasil regresi terhadap variabel pendapatan $(\mathrm{Y})$ dengan variabel biaya (X1) diperoleh nilai t-hitung sebesar 0,0128 . Bila dibandingkan dengan $t-$ tabel yaitu sebesar 2,085, maka nilai $t-$ hitung lebih kecil dari t-tabel $(0,0128<1,705)$. Berdasarkan perhitungan tersebut dapat disimpulkan bahwa biaya bibit (X1) tidak berpengaruh terhadap variabel dependen (produksi telur), kemungkinan karena murahnya harga bibit saat pembelian.

\section{Variabel biaya pakan (X2)}

Tingkat produksi ayam petelur ditentukan oleh pemberian pakan yang tepat. Berkaitan dengan produksi yang dihasilkan perlu diperhatikan komposisi makanan, jumlah, frekuensi serta waktu pemberian makanan. Makanan sangat berpengaruh terhadap produksi telur. Pakan ayam petelur merupakan input variabel yang sangat besar pengaruhnya 
terhadap produksi dan keuntungan. Tingginya harga pakan akan menurunkan keuntungan, sebaliknya jika rendahnya harga pakan maka keuntungan akan meningkat. Oleh karena itu harga pakan memberi pengaruh negatif terhadap pendapatan udaha peternakan (Gunawan, 2019).

Variabel biaya pakan konsentrat $\left(\mathrm{X}_{2}\right)$ setelah dilakukan uji $\mathrm{t}$ ternyata sangat berpengaruh signifikan terhadap pendapatan, karena nilai t-hitung sebesar 1,8599 bila dibandingkan dengan t-tabel yaitu sebesar 2,085 maka nila t-hitung lebih besar dari pada t-tabel $(1,8599>1,705)$.

Hasil analisis dapat disimpulkan bahwa variabel biaya pakan secara individual sangat berpengaruh secara signifikan terhadap pendapatan (Y). Sangat berpengaruhnya biaya pakan kemungkinan disebabkan karena peternak di Desa Klurahan Kecamatan Ngronggot Kabupaten Nganjuk selain menggunakan konsentrat buatan pabrik juga masih mencampur sendiri pakan dengan menambahkan jagung dan bekatul sehingga dapat menekan biaya yang di keluarkan untuk pakan ternak. Biaya pakan sangat berpengaruh terhadap pendapatan dan kualitas telur yang dihasilkan (Sumaryanto, et. al., 2016).

\section{Variabel biaya obat / vaksin (X3)}

Pemberian obat / vaksin dalam pemeliharaan ayam ras petelur merupakan hal yang sangat penting. Vaksinasi dilakukan untuk mencegah dan memberikan kekebalan terhadap penyakit yang dapat menimbulkan kematian ayam. Tingginya tingkat kematian ayam sangat besar pengaruhnya terhadap tingkat keuntungan bahkan dapat menyebabkan kerugian (Kurdi, 2019).
Variabel biaya obat / vaksin (X3) diperoleh nilai t-hitung sebesar 1,2272. Nilai t-hitung lebih kecil dari t-tabel $(1,2272<1,705)$. Berdasarkan perhitungan dapat disimpulan bahwa biaya obat / vaksin (X3) tidak berpengaruh terhadap variabel dependen (pendapatan). Tidak berpengaruhnya biaya obat / vaksin mungkin disebabkan karena peternak memberikan obat sesuai kebutuhan dan anggaran mereka. Sesuai kebutuhan artinya disesuaikan dengan kesehatan ayam petelur, artinya bisa pemberian minimal atau pemberian maksimal. Sesuai anggaran artinya obat yang dibeli disesuaikan dengan dana yang ada.

\section{Variabel biaya tenaga kerja (X4)}

Usaha ternak ayam petelur membutuhkan tenaga yang cakap dalam memelihara ayam. Tenaga kerja tersebut bisa berasal dari sistem keluarga atau sistem upah. Baik atau tidaknya suatu hasil tergantung terhadap proses pemeliharaan, begitu pula sebaiknya. Besar kecilnya produksi akan berpengaruh terhadap keuntungan suatu usaha ternak ayam petelur (Sartika \& Rahmi, 2012)

Variabel biaya tenaga kerja (X4) diperoleh nilan t-hitung sebesar 0,1498. Nilai t-hitung lebih kecil dari pada t-tabel $(0,1498<1,705)$.

Berdasarkan perhitungan tersebut dapat disimpulkan bahwa biaya tenaga kerja (X4) tidak berpengaruh terhadap variabel dependen (produksi telur).

Untuk mengetahui keuntungan usaha peternakan Ayam Ras Petelur di Desa Klurahan, Kecamatan Ngronggot, Kabupaten Nganjuk digunakan rumus $\mathrm{R} / \mathrm{C}$ ratio. Nilai $\mathrm{R} / \mathrm{C}$ ratio pada peternakan Ayam Ras Petelur yaitu sebesar 2,86. Yang berarti usaha peternakan Ayam Ras Petelur sudah 
efisien, karena $\mathrm{R} / \mathrm{C}$ ratio lebih besar dari 1 (2,86> 1). Peternakan Ayam Ras Petelur di Desa Klurahan Kecamatan Ngronggot Kabupaten Nganjuk menguntungkan

\section{KESIMPULAN}

Berdasarkan hasil penelitian dan pembahasan dapat disimpulkan bahwa :

1. Pendapatan yang diperoleh dalam usaha beternak Ayam Ras Jenis Ayam Petelur :

a. Skala usaha 500 ekor $=R p$ 155.694.300

b. Skala usaha 1500 ekor $=R p$ 523.455.514

c. Skala usaha $>5000$ ekor $=R p$ 1.850.211.903

2. Faktor yang berpengaruh sangat signifikan terhadap besarnya produksi ternak ayam ras jenis ayam petelur adalah faktor pakan (X2) sebesar 9,7073 3. Usaha ternak ayam ras petelur termasuk menguntungkan.

\section{DAFTAR PUSTAKA}

Aida, N., \& Alam, M. N. (2015). Analisis Pendapatan Dan Kelayakan Usaha Peternakan Ayam Petelur Hj. Sari Intan di Desa Potoya Kecamatan Dolo Kabupaten Sigi. 3(6), 725730.

Arif, M. (2017). Evaluasi Proyek Analisis Ekonomi. Universitas Indonesia.

Azzury. (2013). Analisis Finansial Usaha Peternakan Ayam Niaga Telur Farm Desa Kucen Kecamatan Mijen Kota Semarang. Jurnal IImuIImu Pertanian, 5(2), 38-49.

Cahyono. (2015). Prinsip Dasar Ekonomi Pertanian. PT Raja Grafindo Persada.
Gunawan, B. (2019). Sukses Abadi Farm (Perencanaan Pengembangan Usaha Ternak Ayam Petelur Closed House).

Kurdi, M. (2019). Kelayakan, Analisis Usaha, Finansial Ras, Ayam Di, Petelur Soddara, Desa Sumenep, Pasongsongan Kabupaten Analysis, Feasibility Of, Financial Chicken, Laying Village, I N Soddara District, Pasongsongan. Jurnal Agri Sains, 3(01), 1-7.

Kurniawan, Y. I., Romadhoni, B., \& Abdullah, I. (2018). ANALISIS KELAYAKAN DAN PERSAINGAN USAHA AYAM PETELUR H. BASO DI KECAMATAN EREMERASA KABUPATEN BANTAENG. 14(2), $1-17$.

Maulana, F. H., Prasetyo, E., \& Sarenggat, E. (2017). Analisis Pendapatan Usaha Peternakan Ayam Petelur Sumur Banger Farm Kecamatan Tersono Kabupaten Batang. Mediagro, 13(2), 1-12.

Muhammad, Hadayani, H., \& Laapo, A (2017). ANALISIS KELAYAKAN FINANSIAL Financial Feasibility Analysis of Laying Hen Farming System at Taufik Nur. Analisis Kelayakan Finansial Usaha Peternakan Ayam Petelur Pada Cv. Taufik Nur Di Kota Palu, 24(1), 18-26.

Mulyani, A., \& Satriani, R. (2013). Feasibility Study of Layer Poultry Farming KWTT "Wanita Karya " at Banyumas District. Jurnal Pembangunan Pedesaan, 13(2), 89-96.

Nawawi, Arif Muhamad, D. (2017). 
Analisis Usaha Peternakan Ayam Petelur Pada Peternakan Ayam petelur Cihaur, Maja, Majalengka, Jawa Barat. 5(1), 15-29.

Ngantung, I. F., Makalew, A., Panelewen, V. V. J., \& Lumenta, I. D. R. (2019). Analisis Rentabilitas Usaha Peternakan Ayam Ras Petelur UD. Tetey Perma di kecamatan Dimembe Kabupaten Minahasa Utara. Zootec, 39(1), 1322.

Pamungkas, M. R., \& Rahayu, S. (2020). KELAYAKAN USAHA BUDIDAYA AYAM PETELUR ( Analisis Biaya Manfaat dan BEP pada UD KR Farm, Cilacap ). 09(01), 40-49.

Prayogo, I. Y., Solikin, N., \& Andaruisworo, S. (2018). Analisis Usaha Peternakan Ayam Petelur (Studi Kasus di Desa Mergayu Kecamatan Ngronggot Kabupaten Nganjuk). Simki-Techsain, 2(2), 17.

Primaditya, F. M., Hidanah, S., \& Soeharsono. (2015). Analisis Pendapatan dan Produktivitas Ayam Petelur Sistem "Closed House" dengan Penggunaan Mesin Pakan Otomatis dan Manual di Kuwik Farm, Kecamatan Badas, Pare. Jurnal Agro Veteriner, 3(2), 99-106.

Rahmi, E., Khairina, E., \& Sartika, W. (2006). Analisis Kelayakan Finansial Usaha Peternakan Ayam Ras Petelur di Kecamatan Guguak Kabupaten Lima Puluh Kota Provinsi Sumatera Barat (Studi Kasus pada Usaha Ayam Petelur Jaka Farm, Kubang Tungkek). Semnas Persepsi III Manado, 579-
588.

Romadhon, H., Gunawan, I., \& Juliani, I. (2012). Analisis Kelayakan Usaha Ayam Ras Petelur (Gallus sp) Studi Kasus pada Usaha Ternak Subur Jln. Teropong KM. 2,5 Kubang Jaya Kabupaten Kampar. Jurnal Penelitian Sungkai, 1(1), 33-40.

Santoso, Z. B., Sudjani, E. T., \& Andaka, A. (2017). Analisis Biaya Produksi Peternakan Ayam Petelur Di Kabupaten Tulungagung. 11(1), 21-29.

Sari, A. I. (2014). Analisis Keuntungan Peternakan Ayam Ras Petelur di Kecamatan Mattiro Bulu Kabupaten Pinrang. Universitas Hasanuddin.

Sartika, W., \& Rahmi, E. (2012). Perkembangan Populasi Ternak Besar Dan Unggas Pada Kawasan Agribisnis Peternakan Di Sumatera Barat. Jurnal Peternakan Indonesia (Indonesian Journal of Animal Science), $\quad 14(3), \quad 466$. https://doi.org/10.25077/jpi.14.3.466 $-472.2012$

Subagja, H., Erlina, N. P., \& Kustiawan, E. (2017). Analisis Kelayakan Peternakan Tradisional Itik Petelur di Kabupaten Jember. Jurnal IImu Peternakan Terapan, 1(1), 39-44.

Sumaryanto, N., Rusastra, I. W., \& Djatiharti, A. (2016). Analisis usaha ayam petelur peternak plasma di Jawa Barat dan Lampung. Forum Penelitian Agro Ekonomi, 7(2), 20. https://doi.org/10.21082/fae.v7n2.1 989.20-31

Ulfa, Z., Sarengat, W., \& Santoso, S. I. (2014). Analisis Finansial Usaha 
Ade Galuh Rakhmadevi \& Danu Indra Wardhana, Analisis Usaha Ayam ...

Peternakan Ayam Petelur UD.

Balebat di Desa Karang Kobar

Kecamatan Sukorejo Kabupaten

Kendal. Animal Agriculture Journal,

3(3), 476-482. 